\title{
Assessment in play-based kindergarten classrooms: An empirical study of teacher perspectives and practices
}

\author{
Angela Pyle \& Christopher DeLuca $^{\mathrm{b}}$ \\ ${ }^{a}$ Ontario Institute for the Study of Education, University of Toronto, Canada \\ ${ }^{b}$ Faculty of Education, Queen's University, Kingston, Canada
}

Full Citation:

Angela Pyle \& Christopher DeLuca (2017) Assessment in play-based kindergarten classrooms: An empirical study of teacher perspectives and practices, The Journal of Educational Research, 110:5, 457-466, DOI: 10.1080/00220671.2015.1118005

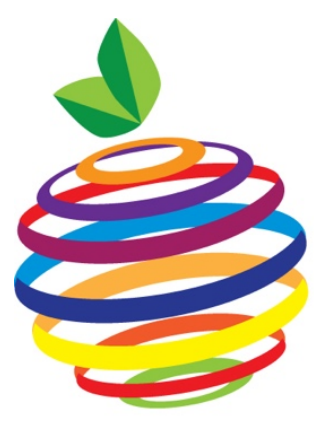

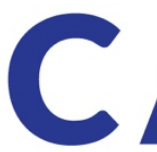

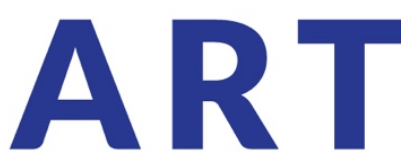

Classroom Assessment

Research Team cdeluca.com
Contact:

Christopher DeLuca cdeluca@queensu.ca

@ChrisDeLuca20 


\begin{abstract}
Kindergarten education is changing. Current reforms have increased accountability structures requiring teachers to integrate assessments throughout their instruction to support academic learning whilst retaining developmentally appropriate pedagogies such play-based learning. Despite these reforms, comparatively little research has been conducted on teachers' assessment practices within play-based instructional contexts. The purpose of this study was to explore teachers' approaches to assessment in play-based kindergarten education and specifically to examine how assessment practices differed based on teachers' conceptions of the purpose of play in student learning. Data were obtained from 77 Ontario kindergarten teachers via (a) an electronic survey, (b) in-depth interviews, and (c) classroom observations. Overall, data from this study suggest a misalignment in teachers' perspectives of the purpose of play and what teachers assess during periods of play.
\end{abstract}

Keywords: kindergarten, early years, assessment, play, teacher practice 


\section{Assessment In Play-Based Kindergarten Classrooms: \\ An Empirical Study Of Teacher Practice}

Recent educational reforms throughout North America have increased academic standards within kindergarten programming. This shift is accompanied by an increased accountability structure, requiring kindergarten teachers to integrate assessments throughout their instruction to support academic learning while retaining developmentally appropriate pedagogies (Ontario Ministry of Education, OME, 2010a; Roach et al., 2010; US DOE, 2010). Specifically, playbased learning has been championed as a developmentally appropriate practice (e.g., MickWayne, 2010; Wallerstedt \& Pramling, 2012) and has served as the foundation for revised curricular policies that mandate the use of play-based pedagogies in kindergarten classrooms (OME, 2010; Pyle \& Bigelow, 2014). Despite these changes, there is limited research to inform teachers' use of assessments to support academic learning within play-based teaching contexts (Brown, 2011; Gullo \& Hughes, 2011; McNair et al., 2003; Pyle \& DeLuca, 2013).

While assessment has been a focal issue in recent years, the vast majority of research has examined large-scale, regional assessments and assessment in the upper years (Brookhart, 2004; Roach et al., 2010). Assessment in early years education has historically focused on constructing standardized tests to measure developmental readiness (Goodman et al., 2000), and only recently has provided an initial conceptual basis for understanding K-2 classroom assessment practices (e.g., Dunphy, 2010; Gullo, 2006). These conceptual underpinnings argue for the continuous use of assessments throughout the learning process to not only monitor and communicate, but also to promote student learning of academic standards. What remains absent from the literature is empirical evidence of teachers' assessment practices within play-based contexts. 
The purpose of this study was to explore teachers' approaches to assessment in playbased kindergarten education. Specifically, we were interested in examining how assessment practices differed based on teachers' conceptions of the purpose of play in student learning. The following questions guided this research:

1. What do teachers believe students learn through play?

2. What learning do teachers assess in play-based Kindergarten contexts?

3. What tools do teachers use to assess learning in play-based Kindergarten contexts? In responding to these questions, our aim was to provide initial evidence of assessment within play-based teaching contexts as a guide to teachers and an incitement for future research.

\section{Play-based Learning Kindergarten Education}

Kindergarten is now included in the elementary education continuum of academic learning (NAEYC, 2009; Wolgemuth, Cobb, Winokur, M. A., Leech, N., \& Ellerby, D. (2006), such that standards must be achieved to ensure that students are prepared for the learning of academic skills in subsequent grade levels (Pyle \& Luce-Kapler, 2013). There is a substantial body of research that validates the importance of academic learning in the early years (e.g., Rushton \& Larkin, 2001, Steele, 2004, McNamara, Scissons, \& Dahleu, 2005), espousing the early years as a critical learning period when the brain allows for greater absorption of information (OME, 2005; Rushton \& Larkin, 2001). For instance, research has shown the importance of phonemic awareness skills to kindergarten students' future development as successful readers (McNamara, Scissons, \& Dahleu, 2005; Pokorni, Worthington, \& Jamison, 2004; Snider, 1997). This body of research describes the need to ensure that the development of academic skills begins in kindergarten to maximize children's success in later grades (e.g., Miller \& Almon, 2009; Steele, 2004). 
However, accompanying this academically oriented research, is an opposing body of research that warns of the potential negative effects of standards that narrow learning to particular academic areas and contain expectations that are developmentally inappropriate (NAEYC, 2009). Researchers in this domain primarily focus on instructional practices rather than curricular standards, espousing the need for educational practices that are developmentally appropriate for young students (e.g., Nie \& Lau, 2010; Parker \& Neuhart-Pritchett, 2006; Stipek, 2004). When considering this perspective, play-based learning presents an enticing pedagogical approach because it is primarily child-centered. Play contexts allow children to guide their learning and thus learn at a pace that aligns with their individual development (Weisberg, HirshPasek, \& Golinkoff, 2013).

Play also provides a potential opportunity to unite academic and developmental orientations to kindergarten education as the benefits of play have been explored in relation to both personal and social development as well as academic learning (e.g., Bodrova, Germeroth, \& Leong, 2013; Saracho \& Spodek, 2006; Van Oers \& Duijkers, 2013). Research that espouses the potential benefits of play has, in turn, influenced curricular policy development that mandate the use of play-based learning pedagogies (e.g., Ontario Ministry of Education [OME], 2010). Ontario, the site of a new Full Day Kindergarten Early Learning Program [FDK] (2010), is one such jurisdiction.

The FDK program in Ontario maintains the academic standards of prior curriculum documents (i.e., OME, 2006; OME, 1998) while mandating a play-based approach to learning that embraces developmentally appropriate practices. This integration of the academic and developmental orientations places Ontario firmly in the center of the seemingly dichotomous bodies of research. While play-based learning presents a potential bridge between these opposing 
camps, the implementation of this pedagogical approach requires that kindergarten teachers negotiate the concurrent implementation of academic learning and play-based pedagogies (Martlew, Stephen, \& Ellis, 2011).

\section{Assessment in Early Education}

Thousands of citations exist on assessment and early childhood education. As early as the 1900s, psychologists (e.g., Piaget, 1964, 1967; Isaac, 1930; Vygotsky, 1986) began measuring children's developmental readiness and demarcating age-specific behavioural expectations through standardized, normative measures (e.g., Goodman et al., 2000). While this research is useful in characterizing students' expected developmental patterns, it provides limited support for teachers' assessment practices because this research is not based within the complex context of classroom instruction and play-based learning. Current research on classroom embedded assessment practices in contemporary kindergarten contexts is exceedingly rare (Gullo \& Hughes, 2011; Roach et al., 2010). The vast majority of recent classroom assessment research has focused on upper-years learning, mainly because the accountability and standards-based movement has only recently begun to impact kindergarten education (Roach et al., 2010; McMillan, Myran, \& Workman, 2002). However, kindergarten teachers are expected to assess students' learning of academic standards and their development. Teachers are further expected to integrate assessment data throughout instruction to monitor student achievement and guide student learning to meet mandated academic standards and developmental targets (Gullo \& Hughes, 2011; Stiggins, 2005). To this end, there has been a resurgence of diagnostic and formative assessment practices to support early years teaching.

While the diagnostic-formative-summative sequence of assessment has traditionally been used to structure assessment integration, more contemporary notions of assessment for and of learning 
have emerged as a set of strategies that involve students in using and understanding assessment data to support and guide learning (Earl, 2003). Specifically, assessment for learning involves actively engaging students in monitoring their learning through self-, peer-, and instructor-based feedback (Assessment Reform Group, 2002), with the aim of not only supporting academic content learning but also learner independence through metacognitive and self-regulation development. Supporting independence through assessment is a critical benefit in early years learning, as one of the fundamental aims of kindergarten is to begin students on a path to independence (Corter Janmohamed, \& Pelletier, 2012). Further, underpinning contemporary processes and uses of assessment is a view of assessment rooted in a socio-developmental theory of learning, which recognizes the importance of classroom context, social interactions, and developmental learning continua as foundational to student learning (Black \& Wiliam, 2006). Brookhart $(2003,2004)$ further asserts the importance of integrating assessment with developmentally appropriate, individualized instruction to move learners from their initial level of knowledge toward the achievement of academic standards; thus there exists a theoretical foundation to connect developmental and academic functions of assessment. However, this foundation has yet to extend to play-based learning contexts in relation to the current curricular context in Canadian schools.

As a practical guide to teachers endeavoring to balance developmental and academic assessment approaches, Gullo and Hughes (2011) identified three principles for kindergarten assessment: (a) assessment of student learning should be a continuous process in classrooms (i.e., assessment for learning), (b) assessment should engage multiple formats (e.g., observation, testing, conversations) appropriate for diverse learners, and (c) assessment should reflect students learning towards academic standards and developmental targets. While these three principles provide general guidance on kindergarten assessment, there remains little empirical research on how 
teachers actually integrate these and other assessment practices in relation to academic curricular expectations and play-based pedagogies.

\section{Method}

Data for this research were obtained from Ontario kindergarten teachers via (a) an electronic survey, (b) in-depth interviews, and (c) classroom observations. The survey was used to explore 67 teachers' approaches to assessment within play-based pedagogical environments. Interviews and classroom observations were then used with 10 focal kindergarten teachers to gather data on teachers' enacted assessment practices in the context of play-based learning. These data collection protocols received both university and school board ethical clearance. Survey

Practicing Ontario kindergarten teachers were recruited to complete the survey via professional networks, email recruitment, and online social media platforms. In total 101 kindergarten teachers responded to the online questionnaire with 67 completing all survey items. The online survey consisted of both close and open-ended questions that were adapted from prior research (Ranz-Smith, 2007) and novel questions that were developed based on data from prior research projects that explored how teachers in full day kindergarten classrooms negotiated the balance between academic learning and developmentally appropriate practices (Pyle \& Bigelow, 2014). Additionally, a series of open-ended questions focused discretely on teachers' approaches to and practices of assessment during play-based learning periods. The survey took teachers approximately 25-35 minutes to complete.

Amongst participants there was a wide variation in their professional backgrounds, with their years of teaching experience ranging from 1 to over 20 years. The average number of years of teaching experience was $13(\mathrm{SD}=6.2)$ years and the average number of years teaching 
kindergarten was 7 years $(\mathrm{SD}=4.3)$. Of the responding teachers, eighty seven percent taught in the public school system. Seventy one percent of participants reported having received training in the use of play as a pedagogical approach for student learning. All teachers in this study were responsible for teaching the Ontario Ministry of Education Kindergarten curriculum with both academic requirements and developmentally appropriate play-based pedagogy.

\section{In-depth Interviews and Classroom Observations}

Ten kindergarten teachers from two public school districts in Ontario, Canada, were selected for this phase of the study. One school district was in a large urban center and one was in a suburban region. The ten teachers had a range of teaching backgrounds (i.e., 3 to 15 years elementary teaching experience; $\mathrm{M}=11.2, \mathrm{SD}=4.1$ years). These teachers also had significant experience specifically at the kindergarten level with years of kindergarten teaching ranging from 3 to $13(M=6.6, S D=3.6)$. In all teachers' classrooms, a minimum of ten hours of observational data were recorded through field notes, photographs, and videos. These observations focused on instructional periods (e.g., circle time, small group instruction) and periods of play, with a focus on the teachers' use of assessment practices. These data were complemented by semi-structured interviews with the classroom teachers that explored their perspectives on the purpose of play in a kindergarten classroom, what they assess during periods of play, and the tools they use to facilitate this assessment.

\section{Data Analysis}

Close-ended survey items provided the demographic statistics for this study. These questions were also used in interviews with the teachers in the 10 focal classrooms. Open-ended survey responses and semi-structured interview questions focused on teachers' perspectives towards learning and assessment in periods of play. These responses were coded individually, 
using qualitative content analysis (Patton, 2014), beginning with an analysis of teachers' perspectives of the role of play in student learning, progressing to teacher descriptions of what they assess during periods of play, and finally analyzing teachers' approaches to assessment in play-based learning with a specific emphasis on the tools used to conduct assessments (Mayring, 2000). The two researchers used an inductive approach to code the survey and interview responses concerning teachers' perspectives of the role of play in learning. This analysis resulted in the identification of three categories: (a) an academic approach to play, (b) a social-emotional approach to play, and (c) a blended approach to play where the goals were both academic and social-emotional. These categories were consistent with prior research concerning play orientations of kindergarten teachers (e.g., Pyle \& Bigelow, 2014).

Using these categories, the two researchers then independently conducted a within category analysis of each participant's responses related to their perspectives towards learning and assessment in periods of play. This coding process specifically focused on analyzing the alignment between a teachers' perspective on the purpose of play in learning with his/her perspective on what could be assessed during periods of play and the tools he/she used to assess student learning during play. All codes were compared across the two raters to ensure a high inter-rater reliability; in the few cases of inconsistencies the raters agreed on code assignment via discussion.

Observational data including field notes, photographs, and videos were then open-coded to provide evidence of the enactment of assessment practices within each classroom. Upon completion of open-coding, the researchers once again used a within category coding procedure to explore the alignment and/or misalignment between teacher approaches to assessment during play-based learning periods and teachers assessment practices in the context of play. Overall, the 
observational data provide evidence of teachers' enacted practices while survey and interview data provide evidence of teachers' perceptions and intentions for assessment during periods of play.

\section{Results}

The results of this study serve to document teachers' approaches to assessment in playbased kindergarten education. Survey and interview results are first presented in relation to teachers' perspectives on (a) the purpose of play, and (b) assessment during play, including their identification of assessment tools. Results from the observational data are then presented to describe the enactment of teachers' assessment practices in play-based learning periods.

\section{Perspectives of the Purpose of Play}

Teachers varied in their perspectives concerning the purpose of play in the kindergarten classroom. Through the coding of participants' survey and interview responses, the vast majority of participants fit into one of two groups: one group focused discretely on the personal and social benefits of play (i.e., developmental perspective); while the other group agreed that play supported personal and social skills development but also expressed that students learned academic expectations through play (i.e., a blended perspective on the purpose of play). A third and much smaller category that emerged in the survey data consisted of teachers who espoused that the primary purpose of play was academic learning. Table 1 presents frequency statistics based on our analysis.

\section{INSERT TABLE 1 HERE}

Of the 67 kindergarten teachers who completed the survey and 10 teachers who were interviewed, $42 \%$ felt that the primary purpose of play was to support the development of personal and social skills. Responses by these teachers are accurately summarized by this 
quotation from one of the participants: "Students are learning to self-regulate their behavior when they play so they will be ready to learn academics. Through play, they build confidence and learn to persevere. They develop social skills needed for collaboration when working in cooperative groups" (Participant 43). Another teacher in this group articulated social development through play as, "the more they play, the more they socialize. The more they play and engage, the more they learn how to work together" (Participant 77).

In total, $50 \%$ of the teachers fit within the blended approach indicating that personal and social skills development were integral to play but that play was also beneficial to the development of academic skills. Due to the integration of personal and social development, and academic skills development, this group of participants is referred to as having a blended orientation to play. The following is a response typical of participants in this group:

Students get to practice skills learned in class (teacher directed lessons), talk with other students during play to solidify their understanding and to think about learning in new ways, practice with explaining, turn taking, cooperating, problem solving, asking questions and problem solving, self regulation of emotions, and the activities are based on self directed choices which makes the students more motivated during their play. (Participant 32)

Similarly, another teacher in this group noted, "Social skills are significantly impacted. Through play, students learn the give and take of conversation and how to work through difficulties. These skills translate to all academic areas as students explain their thinking and listen to other students' ideas" (Participant 37). One teacher elaborated on the process for blending social and academic learning through play by stating: "Children have opportunities to test their ideas and 
try out new materials in a safe place where risk taking is encouraged. Children learn from one another as they share their discoveries" (Participant 50).

The remaining $8 \%$ of teachers communicated the perspective that academic learning was the primary goal of play in kindergarten classrooms. One teacher in this group noted, "I try to use play for children to see how often literacy and mathematics come up and are connected to our daily lives. I use play as the vehicle and hook to teach curriculum concepts" (Participant 54). For teachers in this group, play was a vehicle to reinforce and teach literacy and numeracy skills primarily, with a focus on curriculum expectations and age-appropriate learning. Evident across the data on teachers' perspectives toward the purpose of play is the vast recognition that play serves developmental - social and personal - learning goals with over half also endorsing play as a pedagogy for academic learning.

\section{Assessment during Play}

In addition to sharing their perspectives of the purpose of play, many of the teachers described assessment as the primary challenge in developing a cohesive play-based pedagogy. Several teachers expressed the view that assessment was a persistent challenge to play-based learning. One teacher stated, "assessment is the most difficult part of play-based learning and is an on going challenge" (Participant 18). Further explicating this challenge, another participant stated that while "many areas can be covered, such as math, languages, science, social studies, arts through play, it is a very busy and chaotic environment. So systematic tracking of student learning on site is near impossible" (Participant 36). Perhaps as a result of this persistent view of assessment as a challenge for play-based pedagogy, we observed significant inconsistencies in the alignment between teachers' perspectives of what is learned through play and what teachers can assess through play (see Table 1). 
Although only $58 \%$ of the survey participants indicated that academic learning was a purpose of play, $83 \%$ indicated that they could assess academic skills and content expectations in the context of play. Initially this may seem a curious discrepancy, however, teachers working within a standards-based system of education often associate assessment tasks with academic curriculum standards. Hence, when asked, "what can be assessed during periods of play" these teachers might be responding to assessment and reporting requirements as linked to curriculum standards rather than fully considering the role of assessment in play. Further, teachers may be using assessment as a means to justify the value of play and thus seek to couple it with the assessment of academic standards. For instance, while one participant expressed the perspective that the true value of play was to enhance students' personal and social skills, this teacher expressed a strongly academic orientation to assessment in the context of play:

Play is important for everything. Play is important for learning and just for the sake of play. I want to let my kids play more but have a hard time 'proving' that the play is valuable because what is valued is test scores, not can children innovate or solve problems or take on roles, the way they do in play. (Participant 52)

The in-depth interviews with 10 teachers enabled these participants to more fully describe their approach to assessment in play periods. Moreover, data from these teachers provide additional evidence on a misalignment between teachers' perspectives on the purpose of play and what they believe can be assessed during play. Of these teachers, four emphasized that play was primarily intended for personal and social skills development, however, only one communicated that the sole purpose of assessment in play was to measure personal and social skills. This participant noted, "We noticed a huge difference in their play because they used to not be able to have discourse but now they are actually able to talk back and forth. That is a huge difference in 
their ability to play and have a conversation" (Participant 77). In contrast, two teachers who shared a personal and social developmental perspective towards play emphasized that the sole purpose of assessment was to measure academic learning: "I know I need to get a comment and I need to know where they are at in relation to the curriculum standards, so it will be a focused assessment...I have an expectation that I'm looking at [that is] pulled from the curriculum" (Participant 71). The fourth teacher in this group communicated a blended orientation to playbased assessment: "I'm looking at what concepts they know. Are they counting things out? Can they count? Are they able to share with friends? Can they play cooperatively" (Participant 68). As evident from these data, there is some misalignment in the role of assessment during play periods for teachers who view play for personal and social development. This trend was not paralleled in the interview data amongst teachers with a blended orientation to play; by and large, these teachers maintained greater alignment between their orientation towards play and their abilities to use assessments to measure academic as well as personal and social learning.

In both survey and interview data, several teachers described how they conducted assessment of both academic as well as social and personal learning during periods of play. One teacher stated, "It's easy for me to ask the students to show me something specific that we have learned (example: show me a sequence with 3 different colors; can you mold the first letter in your name?)" (Participant 24). Another teacher mentioned,

It depends on what they are playing. If they are at the block centre are they aware of the laws of gravity, do they understand that large blocks on top of little blocks will topple, if they don't, they can experiment and learn this on their own or with the help of a friend. Speech and language, how well can they carry on a conversation? Physical abilities- can they ride a bike? Fine Motor skills- can they hold a piece of chalk and draw? What do 
they draw? Alphabets, write their own names? The possibilities are endless. (Participant 29)

Across responses, teachers recognized that it was important for them to ask students questions during play periods to assess their learning. Dialogue and playing alongside students were viewed as methods for integrating assessment and play.

In addition to identifying the focus of their assessments during periods of play, teachers were also asked to list and describe the assessment tools they typically used during play-based learning. Table 2 provides a complete list of the tools identified by teachers in this study disaggregated by group (i.e., academic, blended, and personal and social). The blended group used the greatest diversity of tools, while the social group used the least diversity in their tools relying primarily on observation and tools that supported the recording of these observations. However, participants in all groups described the use of iPads, anecdotal notes, checklists, and photos as tools for assessment during periods of play regardless of what they were assessing.

INSERT TABLE 2 HERE

\section{Enactment of Assessment in Play-based Learning}

Our observational and interview data from the 10 focal classrooms revealed that these teachers fit into one of two groups based on their play orientations: four teachers had a personal and social skills development orientation to play, while six embraced a blended play orientation including both academic, and personal and social skills. However, much like the survey and interview data, teachers' orientations to play did not always align with their assessment goals. While all of these ten teachers described the goal of assessing personal and social development in the context of play, over our 100 hours of play-based observations, we observed very few examples of teachers overtly and formally assessing and recording students' personal and social 
skills. In all, we observed only five incidences where this type of assessment was used. The primary method of assessment for personal and social skills was the recording of anecdotal data based on teacher observations: "What I do most is anecdotal notes. I observe what they are doing on a daily basis. For instance, if they are having some communication issues" (Participant 75). Though many teachers described this strategy in interviews and the survey data, during our observations we only observed one teacher completing a formalized anecdotal note about a students' personal and social development. This teacher had an anecdotal recording sheet with each child's name and the focus of her observations listed at the top: "Focus on turn-taking, sharing, and using words to resolve problems" (Participant 76). The anecdotal comments included information about when a child successfully implemented a social strategy: “[Child] wanted some of her blocks so she gave her some. When [child] was still upset she gave her more," and when the student was unable to resolve the issue: "Became upset when [child] wasn't sharing. Did not use her words, instead just made a sad face." Instead of using an anecdotal note, another teacher photographed the students engaged in a playful learning activity where they were constructing a community in response to a story that had been read aloud. These photographs were then projected on a screen for the whole class to see and the students featured in the photographs were invited to describe what they created and how they worked together to accomplish their goal. While there was no evidence of formally recording personal and social development in this activity, the assessment for learning embedded in this activity provided useful anecdotal data for both students and teachers.

While evidence of the assessment of personal and social skills was somewhat limited, the assessment of academic skills was highly prevalent throughout most of the observed classrooms. Across our observations of assessment of academic learning during periods of play, we noted the 
following prevalent assessment methods: (a) teacher questioning, (b) photographs/videos, and (c) documentation walls. In six of the ten classrooms, teachers were regularly observed asking students about their learning in the context of play and using their responses as opportunities to extend student learning. For instance, in one classroom during a child-directed play period, students were playing with a balance scale and various objects. The children attempted to balance their scales by putting in more and more objects. When one child's scale was unbalanced, the teacher questioned her knowledge of the functioning of a scale and her concept of quantity:

Teacher: Why do you think this side is lower?

Student: Because is has the most.

The student then proceeded to add more items to the other side of the scale (Participant 73).

In addition to teacher in-situ questioning, three teachers used photographs and/or videos of play episodes to elicit whole class discussions and questioning to provide students with feedback on their academic development. For instance, students in one class were playing a game that involved sorting objects according to their initial consonant sound. When they completed their game, the teacher took photographs of their sorted objects. During a subsequent circle time, these photographs were shown to the whole class and the teacher questioned how students knew if an object had been sorted correctly and which, if any, objects had been sorted incorrectly. In this way, recordings of individual students' learning during play became an impetus for whole class learning of academic concepts.

Photographs of students at play were also used in the creation of documentation walls in eight of the focal classrooms, which focused on a variety of aspects of students' academic learning through play. In five classrooms, these documentation walls provided evidence of 
student inquiries within the context of their play. For example, one group of students was interested in the concept of 'building.' These students decided to explore all the items in the classroom that they could build something with. The teacher took photographs of these students with their building materials and posted them on the documentation wall with writing samples from the students about their buildings. In four classrooms, the documentation walls focused on the variety of activities that the students chose to participate in during periods of play. These walls included photographs and drawings of students at play accompanied by short descriptions of the play written by the students.

The high degree of photographs, videos, and documentation walls observed in this study suggest the growing prevalence of visual data within kindergarten classrooms. During interviews, teachers emphasized the opportunities presented by collecting visual data: "A lot of photo documentation because there is not always time in the moment to sit down and discuss it with the child, so you can go back to it" (Participant 71). However, despite the frequency of their collection, visual data also presented many challenges that were shared equally by teachers. Pragmatically, some teachers expressed concerns about the need for parental consent before taking visual data of children: “We've got our waivers signed but we haven't been able to openly document anything because you would have to blur out some [students] that haven't signed. So it just ends up being a bit difficult" (Participant 72). A more common concern among teachers though was the time consuming nature of reviewing the data and converting the information into useable assessment data: "I just find videos take up too much space on the computer, and I find myself not going back to them" (Participant 76); "It was time consuming" (Participant 73). These challenges resulted in teachers collecting a great deal of visual data, but relying frequently on anecdotal notes and questioning (i.e., more traditional assessment approaches) when reporting 
student strengths and weaknesses: "I take a picture of it but then I'll write about it as it's easier for me to go back to that" (Participant 76).

In addition to the challenge presented by visual data assessment methods, many teachers repeatedly expressed a more general difficulty in both integrating and assessing academic learning within the context of play. During one interview, a teacher stated:

I see them doing patterning and then I can sit down with that child and talk to them about it and see do they really understand that this is patterning? That is another hard part about this program. Before, you taught the concept and everybody did the same thing. It was like check, they did it, but this guy doesn't get it so now I can work with him. But in this kind of model, where it is like hey this kid is doing patterning over here! I find it is really hard to keep track so we are constantly trying to figure out ways that we can do it effectively. (Participant 68)

Withdrawing students (individually or in small groups) from periods of play to ensure that they were learning the essential academic skills (i.e., reading, writing, and numeracy) was a common strategy shared across the ten focal teachers. During our observations, nine of the ten classrooms withdrew students during every play period we observed. During withdrawal times, teachers conducted small group instruction and assessed students using more formal methods (e.g., running records, phonemic awareness assessments, and letter sound identification). While most teachers expressed the belief that withdrawal was the most effective means of assessment, one teacher clearly communicated an alternative strategy:

I do have the curriculum for each section of the year; September, October, November has it's own needs that you want to be able to check off. We figure out what we need to focus on, what we haven't seen yet, and purposefully create a learning environment where we 
will see that. It's not always possible to see it in just general play; sometimes you actually have to be purposefully looking for it. (Participant 77)

In this classroom, the academic focus was on the development of students' writing skills. To encourage the inclusion of this writing in the context of play, the teacher and students collaboratively created a post office where students could play the roles of the people who worked there and write messages to family and friends. This play context provided many opportunities for the practice and assessment of students' writing. The strategy of purposefully creating contexts of play was observed in many of the focal classrooms, including those that used withdrawal as an assessment strategy.

\section{Discussion}

The kindergarten teachers in this study face the challenge of integrating mandated academic standards into their programs whilst maintaining play-based developmentally appropriate practice. Several policy and curriculum documents throughout Ontario (Ontario Ministry of Education, 2011) and across other educational systems (Roach et al., 2010; US DOE, 2010) encourage teachers to use play pedagogically to support students' academic, personal, and social learning. Moreover, given the expanding accountability framework for public education and its reach towards kindergarten programming, teachers are also required to assess student learning in the context of play, not solely after periods of play. However, despite this changing context for kindergarten teaching, comparatively little research supports teachers' pedagogical efforts to assess academic, personal, and social learning through play-based instruction (Brown, 2011; Gullo \& Hughes, 2011; McNair et al., 2003; Pyle \& DeLuca, 2013). Our interest in this paper was to provide initial empirical evidence on teachers' approaches to assessment within play-based learning environments. Specifically, we sought to analyze the alignment between 
teachers' perspectives on the purpose of play-based learning with what teachers assess during periods of play. We further documented the assessment tools teachers currently use to determine students' learning through play.

Results from this study suggest a misalignment in teachers' perspectives of the purpose of play and what teachers assess during periods of play. In total, $42 \%$ of teachers in this study endorsed personal and social development as the primary function of play-based instruction, with an additional $50 \%$ of teachers supporting both academic and personal and social development through play. However, when asked what learning could be assessed during play periods, teachers shifted their responses across the three identified categories: (a) personal and social, (b) blended, and (c) academic. Fewer teachers indicated that personal and social learning could be assessed during periods of play and nearly double the teachers exclusively supported academic assessments through play. These findings suggest a potential misalignment in teachers' stances towards play, learning, and assessment. Teachers in this study may be reporting higher levels of academic assessment because they believe it is now their professional responsibility to assess academic learning of curriculum standards despite upholding the belief that the fundamental purpose of play is personal and social development. Hence in responding to survey and interview questions, these teachers might have felt a sense of social desirability and professional responsibility to identify academic standards as a focus for their assessment practices.

When examining teachers in the context of their classrooms, we noted that teachers who were committed to a developmental orientation of kindergarten education struggled to reconcile their stance with the academic and assessment demands endorsed by the accountability paradigm of kindergarten education (Dunphy, 2010; Gullo, 2006). While many of these teachers indicated an interest in assessing personal and social learning, our observational data suggest few 
formalized methods for doing so. In contrast, when assessment in the context of play was observed, the focus of the assessment was primarily on the documentation and measurement of academic learning expectations. Our research suggests that there was a diversity of tools that teachers were using to assess academic learning with far fewer strategies to measure students' personal and social development. Through the continued implementation, sharing, and use of these tools, teachers may begin to shift their perspectives on the purpose of play towards a more balanced orientation: those who espouse a strong personal and social orientation to play may begin to see how academic expectations could be taught and assessed; likewise, those who are more committed to academic learning might see value in using documentation tools for learning about students' personal and social development.

Given existing policy and curriculum mandates that endorse the play-based learning of both academic and personal and social expectations (Ontario Ministry of Education, 2011; US DOE, 2010), we see value in supporting teachers' blended orientation towards assessment during periods of play. We further argue that the current play-based learning approach requires that teachers use play-based assessment practices. Our observational data suggested that teachers may be primarily assessing students on their learning after periods of play, rather than during periods of play, as we observed few instances of in-situ play-based assessment. However, through survey and interview data, teachers did report using traditional assessment techniques such as anecdotal records, observation, and questioning during playtime. Some teachers reported augmenting techniques with emerging technologies and newer strategies to measure learning. We did find some observational evidence for technology-enhanced assessment during periods of play, and teachers further articulated some of the challenges and opportunities of this strategy during their interviews. The incongruence between teachers' articulated assessment practices and the lack of 
assessment we observed during play periods suggests that teachers may not know how to implement play-based assessments or that they are not confident in doing so (Charlesworth, Hart, Burts, \& Hernandez, 1991; Wen, Elicker, \& McMullen, 2011).

Supporting teachers in enhancing their assessment competencies in relation to play-based learning of academic, personal, and social expectations is the next step. Broadly, previous research has indicated that teachers struggle to implement contemporary assessment theory and policy into their practice (DeLuca \& Klinger, 2010; MacLellan, 2004). The kindergarten context may be no different. At present, the teachers in this study appear to be wrestling with understanding play pedagogy and are focused on finding and generating assessment tools to measure student learning during periods of play. These teachers largely have a tool-driven understanding of assessment, focusing on 'how to' assess academic or personal and social development. Few teachers articulated how one tool could be used for multiple purposes (i.e., to measure both academic and personal and social learning), suggesting that teachers are still at an initial stage of exploring assessment practices in play-based contexts.

Closely coupled with the need to move teachers away from a tool-driven orientation towards assessment, in which student assessment is moderated (and limited) by the assessment tool, is the need to support teachers in mining and using assessment information once obtained. The result of technology-based assessment (i.e., photographs, ipad apps, and videos) is the generation of a significant amount of visual data on student learning. Several teachers in this study noted that the potential and amount of visual data could be daunting and that teachers needed the skills to mine data for its important information. For example, video evidence provides the opportunity for teachers to revisit student learning during play, however, this process takes time and teachers still need to know "what to look for" (teacher) and how to 
analyze it. Again, previous research has indicated that data literacy is a persistent challenge amongst educators (Lee \& Wiliam, 2005; Popham, 2004, 2011; Stiggins, 2004), with arguments endorsing prolonged, job-embedded, and collaborative learning models focused on data use and evidence-informed teaching (Darling-Hammond \& Richardson, 2009; Hargreaves, 2007; Speck \& Knipe, 2005).

Working to support teachers' assessment competency - their knowledge and skill at constructing, analyzing, and using assessment information - within the context of kindergarten play-based education appears key to fully enacting this pedagogical approach within an accountability framework of public education. As recognized by Brandsford et al. (2000), a fundamental requirement in supporting new concepts and practices is providing learners with a conceptual foundation. In this case, teachers need a guiding framework for negotiating multiple conceptions - purposes and practices - of assessment in relation to their pedagogical approach and current kindergarten policies. Currently there is a dearth of research guiding kindergarten teachers' assessment practices in play-based contexts (Brown, 2011; Pyle \& DeLuca, 2013). Hence future research should work to support teacher learning and teacher practice by linking existing policies, potential practices, and contemporary theory together into a comprehensive framework for teacher use. When teachers are competent in assessment and when assessment works seamlessly to complement their pedagogical approach, they are able to leverage information on student learning to promote academic, personal, and social growth in children. 


\section{References}

Assessment Reform Group. (2002). Assessment for learning: 10 principles. University of Cambridge, UK: Author.

Black, P., \& Wiliam, D. (1998). Inside the black box. London, UK: King's College.

Black, P., \& Wiliam, D. (2006). Developing a theory of formative assessment. In J. Gardner (Ed.), Assessment and learning (pp. 81-100). London, UK: Sage.

Bodrova, E., Germeroth, C., \& Leong, D. J. (2013). Play and self-regulation: Lessons from Vygotsky. American Journal of Play, 6(1), 111-123.

Brandsford, J. D., Brown, A. L., Cocking, R. R., Donovan, M. S., \& Pellegrino, J. W. (Eds.). (2000). How people learn: Brain, mind, experience, and school. Washington, DC: National Academy Press.

Brookhart, S. (2004). Classroom assessment: Tensions and intersections in theory and practice. Teachers College Record, 106, 429-458.

Brookhart, S. M. (2003). Developing measurement theory for classroom assessment purposes and uses. Educational Measurement: Issues and Practice, 22(4), 5-12.

Brown, C. (2011). Searching for the norm in a system of absolutes: A case study of standards- based accountability reform in pre-kindergarten. Early Education and Development, 22, 151-177.

Charlesworth, R., Hart, C.H., Burts, D.C., \& Hernandez, S. (1991). Kindergarten teacher beliefs and practices. Early Child Development and Care, 70(1), 17-35. 
Corter, C., Janmohamed, Z., \& Pelletier, J. (Eds.). (2012). Toronto First Duty Phase 3 Report. Toronto, ON: Atkinson Centre for Society and Child Development, OISE/University of Toronto.

Darling-Hammond, L., \& Richardson, N. (2009). Research review/teacher learning: What matters. Educational Leadership, 66, 46-53.

DeLuca, C., \& Klinger, D. A. (2010). Assessment literacy development: Identifying gaps in teacher candidates' learning. Assessment in Education: Principles, Policy \& Practice, $17(4), 419-438$.

Dunphy, E. (2010). Assessing early learning through formative assessment: Key issues and considerations. Irish Educational Studies, 29(1), 41-56.

Earl, L. (2003). Assessment as learning: Using classroom assessment to maximise student learning. Thousand Oaks, CA: Corwin Press.

Goodman et al. (2000)

Gullo, D. F. (2006). Assessment in kindergarten. In D. F. Gullo (Ed.), K Today: Teaching and Learning in the Kindergarten year (pp. 138-150). Washington, DC: NAEYC.

Gullo, D. F., \& Hughes, K. (2011). Reclaiming kindergarten: Part I. Questions about theory and practice. Early Childhood Education Journal, 38, 323-328.

Hargreaves, A. (2007). Sustainable professional learning communities. In L. Stoll \& K. Seashore Louis (Eds.), Professional Learning Communities: Divergence, Depth and Dilemmas (pp. 181-195). New York: McGraw Hill/Open University Press.

Isaacs, S. S. (1930). The intellectual growth of young children. Londong, UK: Routledge and Kegan Paul. 
Lee, C., \& Wiliam, D. (2005). Studying changes in the practice of two teachers developing assessment for learning. Teacher Development, 9(2), 265-283.

MacLellan, E. (2004). Initial knowledge states about assessment: Novice teachers' conceptualizations. Teaching and Teacher Education, 20, 523-535.

Martlew, J., Stephen, C., \& Ellis, J. (2011). Play in the primary school classroom? The experience of teachers supporting children's learning through a new pedagogy. Early Years, 31(1), 71-83. doi: 10.1080/09575146.2010.529425 conceptualizations. Teaching and Teacher Education, 20, 523-535.

Mayring, P. (2000). Qualitative content analysis. Forum: Qualitative Social Research, 1(2). Retrieved from: http://www.qualitative-research.net/index.php/fqs/article/view/1089/2385

McMillan, J. H., Myran, S., \& Workman, D. (2002). Elementary teachers' classroom assessment and grading practices. The Journal of Educational Research, 95(4), 203.

McNair, S., Bhargava, A., Adams, L., Edgerton, S., \& Kypros, B. (2003). Teachers speak out on assessment practices. Early Childhood Education Journal, 31(1), 23-31.

McNamara, J. K., Scissons, M., \& Dahleu, J. (2005). A longitudinal study of early identification markers for children at-risk for reading disabilities: The Matthew effect and the challenge of over-identification. Reading Improvement, 42(2), 80-97.

Miller, E., \& Almon, J. (2009). Crisis in the Kindergarten: Why Children Need to Play in School. Education Digest, 75(1), 42-45.

Myck-Wayne, J. (2010). In defense of play: Beginning the dialog about the power of play. Young Exceptional Children 13(4), 14-23. doi: 10.1177/1096250610376616 NAEYC. (2009). Developmentally Appropriate Practice in Early Childhood Programs Serving Children from Birth through Age 8 A position statement of the 
National Association for the Education of Young Children. Available online at: http://www.naeyc.org/files/naeyc/file/positions/position\%20statement\%20Web.pdf,

Nie, Y., \& Lau, S. (2010). Differential relations of constructivist and didactic instruction to students' cognition, motivation, and achievement. Learning and Instruction, 20, 411-423.

Ontario Ministry of Education. (2010). The Full-day Early Learning Kindergarten Program. Toronto, ON: Queen's Printers for Ontario.

Ontario Ministry of Education. (2006). The Kindergarten Program (Revised). Toronto, ON: Queen's Printer for Ontario.

Ontario Ministry of Education. (2005) Education for all. The report of the expert panel on literacy and numeracy instruction for students with special education needs, kindergarten to grade 6 (Toronto: Queen's Printer for Ontario).

Ontario Ministry of Education and Training. (1998). The Kindergarten Program. Toronto, ON: Queen's Printer for Ontario.

Parker, A., \& Neuharth-Pritchett, S. (2006). Developmentally appropriate practice in kindergarten: Factors shaping teacher beliefs and practice. Journal of Research in Childhood Education, 21(1), 65-78.

Piaget, J. (1964). Part 1: Cognitive development in children: Piaget development and learning. Journal of Research in Science Teaching, 2(3), 176-186.

Piaget, J. (1967). Biology and Knowledge. Chicago: University of Chicago Press.

Pokorni, J. L., Worthington, C. K., \& Jamison, P. J. (2004). Phonological awareness intervention: Comparison of fast ForWord, earobics, and LiPS. The Journal of Educational Research, 97(3), 147-147+. 
Popham, J. W. (2013). Classroom assessment: What teachers need to know (7th ed.). New York, NY: Pearson.

Pyle, A., \& Bigelow, A. (2014). Play in kindergarten: An interview and observational study in three Canadian classrooms. Early Childhood Education Journal. doi: $10.1007 / \mathrm{s} 10643-014-0666-1$

Pyle, A. \& DeLuca, C. (2013). Assessment in the kindergarten classroom: An empirical study of teachers' assessment approaches. Early Childhood Education Journal, 41(5), 373-380.

Pyle, A., \& Luce-Kapler, R. (2014). Looking beyond the academic and developmental logics in kindergarten education: The role of Schwab's commonplaces in classroom-based research. Early Child Development and Care, 184(12), 1960-1977. doi: $10.1080 / 03004430.2014 .897945$

Ranz-Smith, D. J. (2007). Teacher perception of play: In leaving no child behind are teachers leaving childhood behind? Early Education and Development, 18(2), 271-303.

Roach, A. T., Wixson, C., \& Talapatra, D. (2010). Aligning an early childhood assessment to state kindergarten content standards: Application of a nationally recognized alignment framework. Educational Measurement: Issues and Practice, 29(1), 25-37.

Rushton, S., \& Larkin, E. (2001). Shaping the learning environment: Connecting developmentally appropriate practices to brain research. Early Childhood Education Journal, 29(1), 25-33.

Saracho, O. N., \& Spodek, B. (2006). Young children's literacy related play. Early Child Development and Care, 176(7), 707-721.

Snider, V. E. (1997). The relationship between phonemic awareness and later reading 
achievement. The Journal of Educational Research, 90(4), 203.

Speck, M., \& Knipe, C. (2005). Why can't we get it right? Designing high-quality professional development for standards-based schools (2nd ed.). Thousand Oaks, CA: Corwin.

Steele, M. M. (2004). Making the case for early identification and intervention for young children at risk for learning disabilities. Early Childhood Education Journal, 32(2), 75-79.

Stiggins, R. (2005). From formative assessment to assessment for learning: A path to success in standards-based schools. Phi Delta Kappan, 87(4), 324-328.

Stiggins, R. (2004). New assessment beliefs for a new school mission. Phi Delta Kappan, 86, 2227.

Stipek, D., \& Byler, P. (2004). The early childhood classroom observation measure. Early Childhood Research Quarterly, 19, 375-397.

US Department of Education. (2010). A blueprint for reform: The reauthorization of the Elementary and Secondary Education Act. Washington, DC: Author.

Van Oers, B., \& Duijkers, D. (2013). Teaching in a play-based curriculum: Theory, practice and evidence of developmental education for young children. Journal of Curriculum Studies, 45(4), 511-534.

Vygotsky, L. S. (1986). Thought and language (A. Kozulin, Trans.). Cambridge, MA: MIT Press. (Original work published 1934)

Wallerstedt, C., \& Pramling, N. (2012). Learning to play in a goal-directed practice. Early Years, 32(1), 5-15.

Weisberg DS, Zosh JM, Hirsh-Pasek K and Golinkoff RM (2013) Talking it up: Play, language development, and the role of adult support. American Journal of Play 6(1), 39-54.

Wen, X., Elicker, J. G., \& McMullen, M. B. (2011). Early childhood teachers' curriculum 
beliefs: Are they consistent with observed classroom practices. Early Education and Development, 22(6), 945-969.

Willis, J. (2010). Assessment for learning as a participatory pedagogy. Assessment Matters, 2, 65-84.

Wolgemuth, J. R., Cobb, R. B., Winokur, M. A., Leech, N., \& Ellerby, D. (2006). Comparing longitudinal academic achievement of full-day and half-day kindergarten students. The Journal of Educational Research, 99(5), 260-269. 